\title{
Dos textos sufragistas ingleses
}

\author{
Two English SuffragetTe teXTs
}

\author{
Silvina Sartelli \\ University of Notre Dame \\ http://orcid.org/0000-0003-2559-168X \\ ssartell@alumni.nd.edu
}

Al final de esta sección fueron seleccionados dos documentos correspondientes al movimiento sufragista que tuvo lugar en Inglaterra a comienzos del siglo XX. Se presentan ambos textos en su versión original en inglés, acompañados de su traducción.

En primer lugar, se incluye una carta suscripta por Emmeline Pankhurst, líder de la Unión Política y Social de las Mujeres (UPSM), organización fundada en 1903 por la misma Pankhurst. Fiel a su perfil activista, en este documento Pankhurst hace un llamado a las mujeres a tomar parte del proceso tendiente a la consecución del voto femenino y a comprometerse con la militancia del grupo. La UPSM se caracterizó por el empleo de tácticas violentas con el fin de avanzar en el logro de los objetivos preestablecidos. La riqueza del texto radica en la fuerza con que la principal promotora del movimiento sufragista inglés expone la necesidad de abandonar los medios pacíficos para pasar a la acción, idea que se condice con el lema que rigió a la organización: "Hechos, no palabras" [Deeds, not words].

En segundo lugar, se seleccionó un texto que muestra la otra cara del movimiento sufragista. Es el caso de una vińeta antisufragio que forma parte de un volumen de tarjetas publicadas en 1910. En su mayoría, 
estas viñetas, redactadas en tono satírico, reemplazaban la reconocida rima infantil "This is the House that Jack Built" por "This is the House that Man Built", en clara referencia al Parlamento Británico, centro de conflicto entre las sufragistas y los parlamentarios, en su mayoría reacios a introducir la enmienda necesaria para ampliar el sufragio al colectivo femenino. Sin embargo, en la vińeta aquí incluida la expresión "the House" alude a la prisión Holloway, donde muchas activistas fueron encarceladas y sometidas a prácticas inhumanas como la alimentación forzada.

\section{Texto $\mathrm{N}^{\circ} 1$}

Carta escrita por Emmeline Pankhurst a los miembros de la Unión Social y Política de las Mujeres, el 10 de enero de 1913, delineando los argumentos en favor de la militancia.

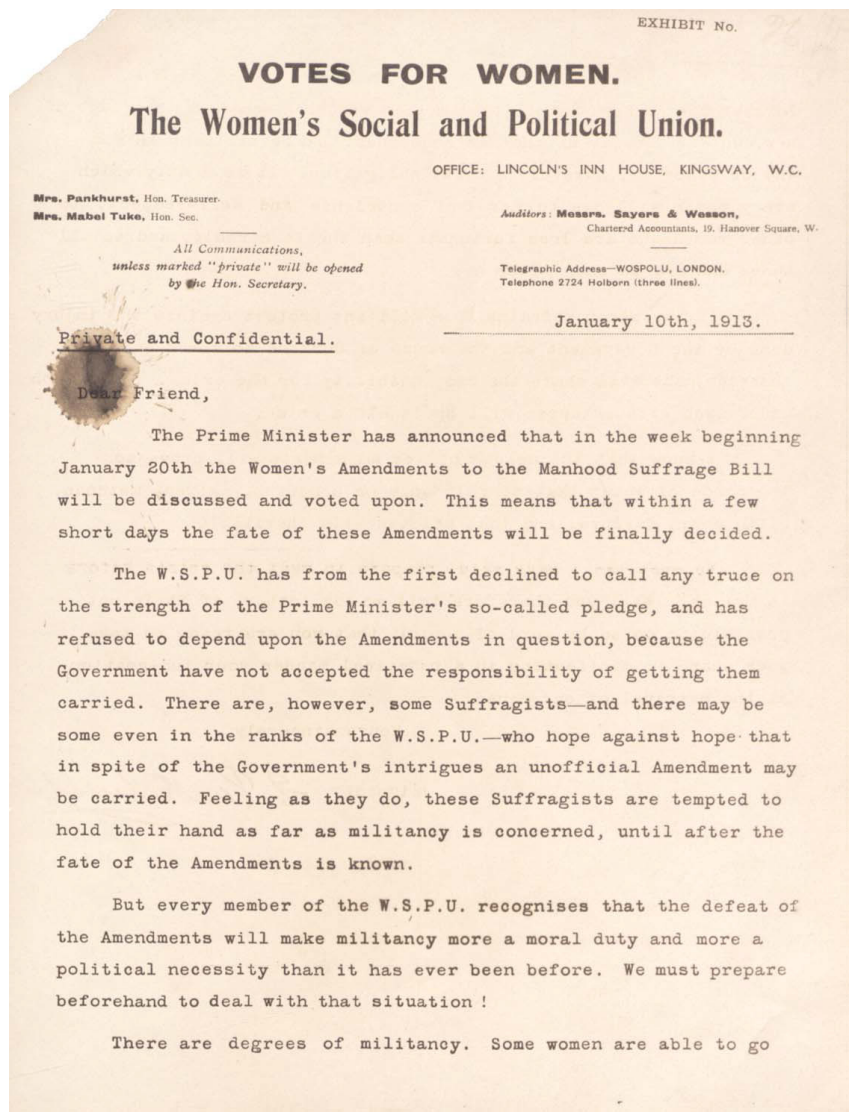


further than others in militant action and each woman is the juage of her own duty so far as that is concerned. To be militant in some way or other is, however, a moral obligation. It is a duty which every woman will owe to her own conscience and self-respect, to other women who are less fortunate than she is herself, and to all those who are to come after her.

If any woman refrains from militant protest against the injury done by the Government and the House of Commons to women and to the race, she will share the responsibility for the crime. under such circumstances will be itself a crime.

I know that the defeat of the Amendments will prove to thousands of women that to rely only on peaceful, patient methods, is to court failure, and that militancy is inevitable.

We must, as I have said, prepare to meet the orisis before it arises. Will you therefore tell me (by letter, if it is not possible to do so by word of mouth), that you are ready to take your share in manifesting in a practical manner your indignation at the betrayal of our cause. Yours sincerely, (Signed)

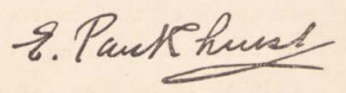

Fuente: The National Archives, UK, Documento CRIM 1/139/2 


\section{VOTOS PARA LAS MUJERES}

\section{La Unión Política y Social de las Mujeres}

Señora Pankhurst, Hon.

Tesorera.

Mrs. Mabel Tuke, Hon.

Secretaria

Chartered Accountants, 19. Hanover Square, W.
Todas las comunicaciones, al menos que indiquen "privada", serán abiertas por la Hon. Secretaria

OFICINA: LINCOLN'S INN HOUSE, KINGSWAY, W.C.

Auditores: Messrs. Sayers \& Wesson

Dirección Telegráfica - WOSPOLU, LONDRES

Teléfono2724 Holborn (tres líneas)

\section{Privado y Confidencial}

\section{Querida amiga,}

El Primer Ministro ha anunciado que en la semana del 20 de enero el proyecto de ley sobre las Enmiendas de las Mujeres al Sufragio Masculino será discutido y votado ${ }^{1}$.

La USPM siempre ha rehusado llamar a un acuerdo para detener la violencia sobre la base de la promesa del Primer Ministro y ha rehusado

1 [N. del T]. Herbert Henry Asquith planeaba introducir enmiendas para dar el voto a las mujeres cuando el Proyecto fuera discutido en la Cámara de los Comunes. 
depender de las Enmiendas en cuestión. El gobierno no nos ha dicho que se convertirán en ley.

Hay algunas Sufragistas, y posiblemente algunas Suffragettes, que tienen la esperanza que una Enmienda no oficial pueda ser convertida en ley. Ellas piensan que pueden detener cualquier acto militante hasta que el destino de las Enmiendas sea conocido.

Pero cada miembro de la USPM sabe que el fracaso de las Enmiendas hará de la militancia una obligación moral. Será una necesidad política. Debemos prepararnos ahora.

Hay distintos grados de militancia. Algunas mujeres son capaces de ir más lejos que otras. Ser militante de alguna manera es una obligación moral. Cada mujer lo debe a su propia conciencia y a su respeto propio, $\mathrm{y}$ a las futuras generaciones de mujeres.

Si cada mujer no toma parte en la acción militante, comparte el crimen del Gobierno.

Sé que la derrota de las Enmiendas le mostrará a miles de mujeres que la militancia es inevitable. Los métodos pacíficos fracasan.

Debemos prepararnos para esto ahora. Dime, por carta, o de boca en boca, que estás lista para formar parte de la militancia.

Sinceramente,

Firmado: E. Pankhurst 


\section{Texto $\mathbf{N}^{\circ} 2$ - Vińeta}

ESTA ES “LA CASA"
QUE EL HOMBRE
CONSTRUYÓ
Y esta es el hogar de la
pobre Suffragette.
Y hay lugar para muchas
más aún,
Cuando hagan alboroto y
disturbios
Y no se queden calladas
Las pondremos sobre
catres y a dieta con pocas
calorías;
Para detener todo su
alboroto
Las arrestaremos
Dentro de ESTA CASA
Que el hombre construyó

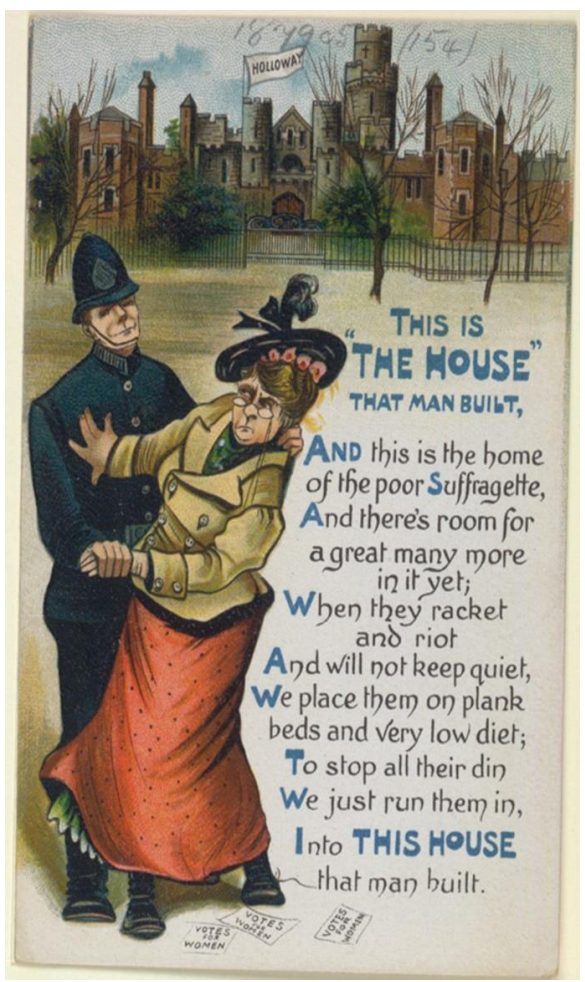

Fuente: The British Library, General Reference Collection 1879.c.5.(154) ${ }^{2}$.

2 Dado que por "sufragistas" se entiende al grupo de mujeres que lucharon por la conquista de los derechos civiles, políticos y laborales, entre fines del siglo XIX y comienzos del XX, su uso expresa una generalidad que no condice con las particularidades de las "suffragettes", feministas que usaron la violencia como bandera de lucha y se nuclearon principalmente en la WPSU. En consecuencia, la traducción de suffragette por sufragistas no es del todo apropiada y ante esta imposibilidad, se optó por mantener la expresión foránea. 